\title{
Research Convergence:
}

\section{Demonstrating Causal Relationships between School Libraries and Student Learning Internationally}

\author{
Barbara Schultz-Jones \\ Barbara.Schultz-Jones@unt.edu \\ University of North Texas
}

\section{Laura Pasquini}

Laura.Pasquini@unt.edu

University of North Texas

Keywords: evidence based practice, causal research, CLASS II, student learning

\begin{abstract}
A subset of international scholarship from the full Causality: School Libraries and Student Success corpus comprising empirical studies conducted in non-American locations $(n=47)$ are examined for: geographic distribution, publication outlets, citations, data collection and analysis methods, and research strands. The majority of papers used one experimental design or two or more methods for quasi-experimental design approach for data collection, and used at least one or more often two or more data analysis methods. Six categories describe the research: learning environment, student attributes, teacher and school leadership characteristics, instructional interventions, academic skill development, and external factors for achievement.
\end{abstract}

\section{Introduction}

School library programs and services add value to the educational community. Substantiating this value is the strong foundation of school library research that has historically used correlational studies to demonstrate the relationship between school libraries and student achievement (Library Research Service, 2018; Williams, Wavell, \& Morrison, K., 2013). These studies identify three features of school librarianship that have an impact on student learning (IFLA, 2015, p. 17):

1. It has a qualified school librarian with formal education in school librarianship and classroom teaching that enables the professional expertise required for the complex roles of instruction, reading and literacy development, school library management, collaboration with teaching staff, and engagement with the educational community.

2. It provides targeted high-quality, diverse collections (print, multimedia, digital) that support the school's formal and informal curriculum, including individual projects and personal development. 
3. It has an explicit policy and plan for ongoing growth and development.

While this research is a solid base to build on, the studies do not demonstrate causal relationships where a specific action or dimension of school librarianship directly causes an impact on student learning. In the educational research field, the "gold standard" is the randomized controlled trial (Sandelowski, Voils, \& Barroso, 2006, p. 5), an experimental design where sources of bias are removed from the process to meet the goal of determining if a specific intervention or condition makes a positive difference to the people receiving it. Causal studies across grade levels and school library contexts could help strengthen the body of evidence of school library research.

The arena of school librarianship is international. We have international School Library Guidelines (IFLA, 2015). "But what about our research? Is it diverse? Are international voices represented? Unfortunately, overwhelming evidence confirms that it is not" (Everhart, 2018, p. i). Our results confirm that the school library research field needs a larger infusion of international contributions.

\section{Statement of the Research Problem}

The American Association of School Librarians (AASL) proposed a research agenda (see Figure 1) as part of their 2014-2015 Causality: School Libraries and Student Success (CLASS) federally funded grant project that began in late 2015 with three teams of researchers from three universities.

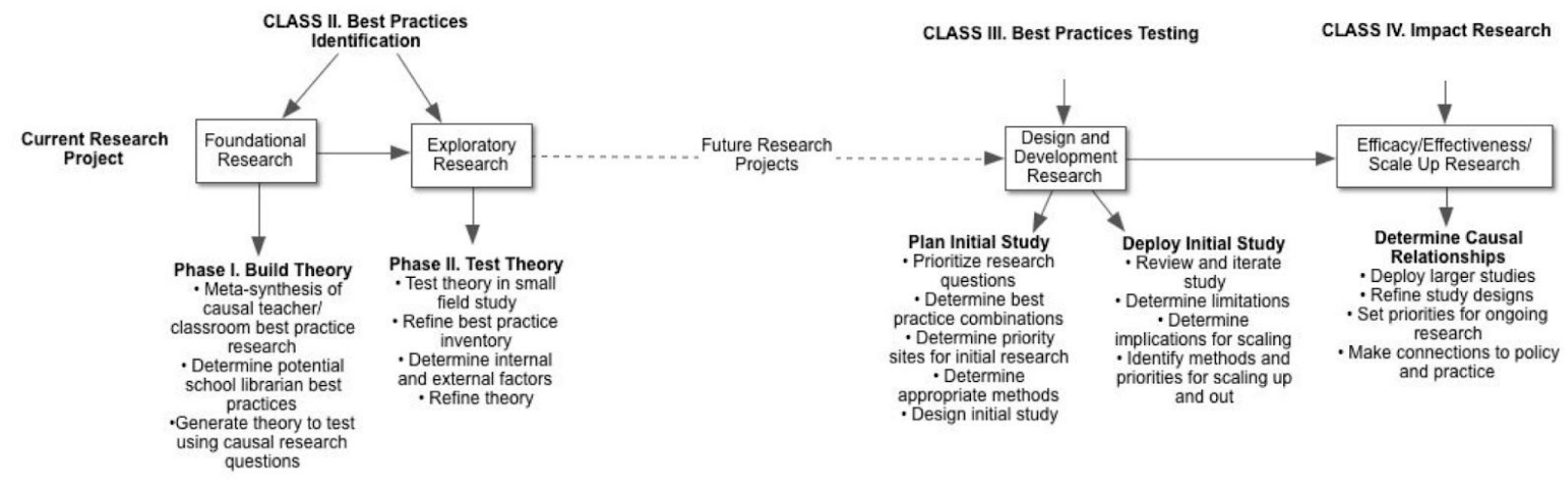

Figure 1. CLASS research agenda phases (AASL, 2014, p. 4)

The research teams include school librarian educators, methodology specialists, practicing school librarians, and doctoral students. They pursued foundational and exploratory research as guided by the expectations for Phase I of AASL's research agenda, with the first stage to develop a meta analyses of existing studies that identify effective practices, processes, and areas to develop a concept map and/or theory of why and how school librarians/libraries affect student outcomes (AASL, 2014).

The following research question focused these efforts: What causal relationships between school-based malleable factors (i.e., aspects within the school environment that can be controlled) and student outcomes are present in published research? From those efforts we narrow the goal to understand CLASS in non-American investigations and to present a comprehensive picture of this international scholarship. For this investigation, we pose the following research questions (RQ), each corresponding to an aspect of this literature review for causal relationship between school libraries and/or school librarianship and student achievement: 
RQ1: How is empirical CLASS research geographically distributed outside of the United States?

RQ2: Where is empirical international CLASS research published, and what are the common publication outlets for this type of scholarship?

RQ3: Which empirical international CLASS studies are cited the most?

RQ4: What data collection and data analysis methods are used in the empirical studies international CLASS investigations?

RQ5: What is the focus of the international CLASS studies? What subjects, topics, or domains are being studied? And, what research questions are being asked within these empirical investigations?

\section{Literature Review}

Research informing school librarianship occurs worldwide. However, as Everhart (2018) reported, of the 16 issues and 115 articles for School Libraries Worldwide, published from 2011-2018, over half of the articles (58\%) were written by U.S. authors, with Canada (6\%) and Australia (5\%) a distant second and third. Branch-Mueller and Beesoon (2015) examined the geographical locations of research published in School Libraries Worldwide, School Libraries Research, and other sources from 2009-2015 and found that of the 100 locations, 77\% were in the U.S. with Australia (5\%) and Canada (4\%) again trailing significantly. Other researchers have reviewed the makeup of school library research studies.

In 2011, Mardis looked at the origin of the first author, the research topics as classified for library and information science (LIS) topics by Järvelin and Vakkari (1990) and as amended by Oberg (2006), and methodologies for research articles presented at the International Association of School Librarianship (IASL) Research Forum 1998-2009 ( $\mathrm{n}=199$ ). In this case, U.S. first authors accounted for 30\% of the research articles with Canadian first authors at $12 \%$ and Australian first authors contributing 10.5\%. The top three topic areas were: information skills and literacy with $28.1 \%(n=56)$, information technology with $10.6 \%(n=21)$, and reading and reading promotion with $9 \%(n=19)$ of the publications. In terms of methodologies, the majority of the research approaches $(n=87)$ used qualitative methods, followed by mixed methods $(n=42)$, literature review $(n=17)$, meta-analysis $(n=3)$, and policy analysis $(n=3)$.

Morris and Cahill (2015) reviewed the research designs of 217 articles published in School Library Research (SLR) and School Libraries Worldwide (SLW) from 2007 through July 2015 to identify methodological changes since the adoption of the 2009 standards by the American Association of School Librarians (AASL). This approach did include an international field since both journals accept international submissions. They also found that the majority of contributors $(n=113)$ are from the United States (71.1\%) with Canada and Australia representing 5\% of contributors each $(n=8)$. Research designs used in the 159 articles that qualified as original empirical research were primarily qualitative $(47.17 \%)$, followed by mixed-methods (33.33\%) and quantitative studies (19.5\%). An interesting component of this review was identifying the limited inclusion of Pre-K-12 students as participants.

Neuman (2003) provided a seminal review of the research conducted in the United States, framed by her explicit statement that "research in school library media should focus explicitly on the relationship between library media programs and student learning" (p. 503). While a methodology for reviewing the literature was not identified, the framework of four research areas was directive: " 1 . What are the contributions of library media programs to student achievement? 2. What are the roles of the library

International Association of School Librarianship

https://iasl-online.org 
media specialist in today's schools? 3. How do students use electronic information resources for learning? 4. What has been the impact of the Information Literacy Skills for Student Learning on library media programs?" (p. 504).

Johnson and Green (2018) used a systematic literature review of the research conducted in the United States and published from 2004-2014 to "identify and synthesize research conducted in relation to school libraries and librarianship, according to the four questions defined by Neuman (2003)" (p. 2). They identified 110 empirical studies and reviewed the research focus, identifying the distribution of publications as follows:

- $47 \%(\mathrm{n}=52)$ presented research related to the roles of the school librarian (teacher, instructional partner, leader, information specialist, program administrator);

- $25 \%(n=28)$ concerned research related to how students use electronic information resources for learning;

- $15 \%(\mathrm{n}=17)$ researched the impact of the 2007 AASL Standards on school library programs; and

- $12 \%(\mathrm{n}=13)$ conducted research related to contributions of school library programs to student achievement.

While a variety of other countries conduct and present research, the individual countries total a low percentage of the contributions. This does not reduce the value of those contributions, but does indicate where the volume of research attention is focused.

As we explore the focus of international research, it is important to be mindful of the context. Pence and Hix-Small (2009) note that the international image of children is increasingly homogeneous and Western-derived and warn against "narrowly framed science" (p. 86) as research is conducted. The IFLA 2015 School Library Guidelines recognize that "programs and activities provided by a school library vary around the world because they need to align with the goals of the school and the broader community" (p.

38). Further:

School library research related to the core activities provides a framework for action. The focus of core activities of a school library will depend on the programs and priorities of a school and should reflect the progression of curriculum expectations from grade to grade. (p. 39).

Within a framework of core activities that includes literacy and reading promotion; media and information literacy; inquiry-based learning (e.g., problem-based learning, critical thinking); technology integration; professional development for teachers; and appreciation of literature and culture:

...evidence-based practice should guide the services and programs of a school library and provide the data needed for improvement of professional practice and for ensuring that the services and programs of a school library make a positive contribution to teaching and learning in the school (IFLA, 2015, p. 11).

The application of evidence-based practice (EBP) to school librarianship emerged from the challenge delivered by Todd (2006) at the International Association of School Librarianship (IASL) annual conference in 2001. Since then school librarians and school library researchers have applied EBP to provide the evidence supporting the decisions they make for practice (foundational, based on research), in practice (locally produced evidence that is transformational), and of practice (outcomes that present the results and impact). This accountability approach can provide strong evidence of the impact that school librarians and school library programs and services effect.

International Association of School Librarianship

https://iasl-online.org 
Building on and responding to Todd's $(2009,2015)$ empirical findings, Lyons (2009) stressed the need for school library research to move away from advocacy-driven research because this motivation inherently directs research questions and drives methodological choices:

Neither formulating a biased question that aims to confirm the relevance and efficacy of an intervention nor compiling impact studies or other campaigns in answer to this question is evidence-based practice. These efforts are pure advocacy and promotion. They are neither impartial nor client-centered. EBP requires that the effectiveness of school libraries in meeting specific student needs to be evaluated in comparison with relevant alternative educational interventions (p. 65).

As a move towards removing bias from school library research, the Mixed Research Synthesis (MRS) method, often used in public health research (Sandelowski, Voils, \& Barroso, 2006; Sandelowski et al., 2012), is considered a strong method to develop evidence summaries, and to determine the effective factors in an implementation chain of interventions, programs, and policies (Pawson, 2006). This approach synthesizes a combination of qualitative, quantitative, and mixed methods studies, and applies a mixed methods approach to integrate those studies, for the broad purposes of breadth and depth of understanding and corroboration (Heyvaert et. al., 2013, p. 662). The intention is identifying promising causal relationships from the original research study context that can be further developed as evidence.

\section{Methodology}

Data Collection

To be included in the corpus, each identified publication would focus on international CLASS research and would have been (1) empirical, (2) published in a peer-reviewed journal, report, or conference proceeding, (3) published or available online as in press between 1985-2015, (4) written in English, and (5) investigations or studies conducted outside of the United States. We defined empirical publications as papers that gathered and analyzed primary or secondary data in their investigation. Papers with conceptual or theoretical focus were eliminated, as they did not meet the inclusion criteria.

A MRS approach identified and aggregated activities and features with strong relationships related to student learning, using three independent and concurrent meta-syntheses of current education policy, theory, and best practices research (Schultz-Jones et al., 2018). Each team chose a corpus of peer-reviewed internationally published research on causes of student learning published between 1985 and 2015. The aggregated corpus of studies were synthesized by each team and crosschecked within each team. The teams combined aggregation with cross-team coder agreement that removed duplicate publications to produce a final dataset of 305 studies containing causal education research studies.

For the purpose of this paper, we are reviewing only non-American and mixed country studies from the larger CLASS II research database $(n=305)$, which represents $15.4 \%(n=47)$ of the complete corpus. Publications in the corpus had at least one publication available for each year, during the designated time span (1985-2015), except for the years: 1985, 1989, 1993, 1994, 1996, 2004, 2012, and 2014.

\section{Data Classification and Analysis}

We analyzed the forty-seven papers utilizing both quantitative and qualitative approaches. We describe this classification and analytic method used in relation to each research question.

To determine the geographic distribution of international CLASS research (RQ1), we coded the country by the associated study region. To determine where the paper was published (RQ2), we classified each publication according to its outlet (e.g. journal, conference proceeding, report, etc.) and then counted the number of times these publication outlets appeared in our corpus. To determine which studies were cited

International Association of School Librarianship

https://iasl-online.org 
the most (RQ3), we identified each paper in our corpus on Google Scholar and noted its citation count (Figure 1) at the time this paper was submitted (July 27, 2019).

To outline the focus of the investigations in the corpus (RQ5), two researchers independently read and assigned emerging codes to each paper based on the abstracts and research questions. The first researcher generated 69 codes and the second researcher generated 66 codes. Next, they met to discuss their findings and identify categories describing their codes and come to agreement of codes for the overarching themes. They identified six central categories, grouping the focus of the research questions: classroom setting and learning environment; student-focused issues and attributes; school, teacher and school leadership characteristics; instructional interventions and pedagogical practices; targeted academic skill development; and external factors for achievement (e.g. family, economics, community, etc.). Next, they returned to the papers and independently assigned the research questions from each publication to each theme. Consensus making approaches resolved any differences. Finally, they discussed the discrepancies and resolved them, reaching agreement on all papers in the corpus. The final dataset consisted of eighty-three research questions assigned to six themes.

\section{Limitations}

1. This study clarifies the state of causal impact empirical literature published during a specific point in time using a particular methodology. There are three limitations arising from this investigation context. First, the data analysis methods used in this study do offer judgment about the quality of the research reported. Therefore, it should be recognized that the papers included in our corpus are of mixed quality. Second, while our data reflect some content of the papers analyzed, they do not reflect a full evaluation of the contents of the paper (e.g. the results reported for each research strand). Third, while non-English native speakers author papers on causal impact, the choice to exclude papers written in languages other than English may have limited the size and diversity of the sample. Future investigations would solicit support of non-English scholars to broaden the scope of this investigation.

\section{Findings RQ1: How is empirical CLASS research geographically distributed outside of the United States?}

This question asks where causal impact research is being conducted, specifically what geographic regions are associated with this type of scholarship. The majority of papers had studies from multiple countries (23.4\%); these studies were meta-analyses of research studies from multiple countries, comparison of standardized test data from multiple regions (e.g. PISA, TIMSS, etc.) or findings analyzed between one country in contrast to the United States (e.g. Netherlands and Australia). Table 1 shows the frequency and percentage of each country from where the papers originate from in the corpus. 


\begin{tabular}{|lcc|}
\hline Table 1 & & \\
Frequency (Percentage) of Each Country from & the Associated Study \\
\hline Country & Number & \% of Corpus \\
Multiple Countries* & 11 & 23.4 \\
Canada & 8 & 17.0 \\
Australia & 4 & 8.5 \\
Hong Kong & 4 & 8.5 \\
Netherlands & 4 & 8.5 \\
Israel & 3 & 6.4 \\
Belgium & 2 & 4.3 \\
Japan & 2 & 4.3 \\
Great Britain & 1 & 2.2 \\
New Zealand & 1 & 2.2 \\
Norway & 1 & 2.2 \\
Singapore & 47 & \\
Taiwan & 1 & 2.2 \\
Totals & 1 & \\
\hline There are at least five studies identified in the "Multiple Countries" country category \\
that include USA in this aggregated sample.
\end{tabular}

Beyond the multiple country studies, Table 1 shows the majority of international scholarship focused on North America (27.7\%), Europe (17.5\%), and Oceania (10.7\%). There is no representation of scholarship from Africa or South America in this corpus.

\section{RQ2: Where is empirical international CLASS research being published, and what are the common} publication outlets for this type of scholarship?

There were forty-four papers published in peer-reviewed journals and three papers published as academic reports. There were thirty-two publication outlets with five outlets being journals that included at least two or more papers in each (see Table 2). These five top outlets are academic publication outlets that focus on research in education research, educational psychology, and library/information science, with two of these journals published from the American Educational Research Association (AERA) in the United States. 


\begin{tabular}{|lc|}
\hline $\begin{array}{l}\text { Table } 2 \\
\text { Top Journal Outlets for Publishing International CLASS Research }\end{array}$ \\
\hline Journal Publication Name & Number of Papers \\
Review of Educational Research & 6 \\
British Journal of Educational Psychology & 5 \\
Journal of Educational Psychology & 4 \\
Library \& Information Science Research & 3 \\
American Educational Research Journal & 3 \\
Totals $(n=47)$ & 21 \\
\hline
\end{tabular}

RQ3: Which empirical international CLASS studies are cited the most?

At the time of writing, all forty-seven papers were cited at least once. Four of the papers were cited between one (2), four (1), and six (1) times. There were seventeen papers cited between ten to 199 times and sixteen papers cited between 200 to 699 times. The top ten papers for impact were cited over 700 times and are itemized in Table 3.

Table 3

International CLASS Publications Cited Most Frequently

\section{$\underline{\text { Paper Citations }}$}

Angrist, J. D., \& Lavy, V. (1999). Using Maimonides' rule to estimate the effect of class size on scholastic achievement. The Quarterly Journal of Economics, 114(2), 533-575.

Marsh, H. W, Trautwein, U., Lüdtke, O., Koller, O., \& Baumert, J. (2005). Academic self-concept, interest, grades and standardized test scores: Reciprocal effects models of causal ordering. Child Development, 76, 397-416.

Guay, F., Marsh, H. W., \& Boivin, M. (2003). Academic self-concept and academic achievement: Developmental perspectives on their causal ordering. Journal of Educational Psychology, 95(1), 124.

Seidel, T., \& Shavelson, R. J. (2007). Teaching effectiveness research in the past decade: The role of theory and research design in disentangling meta-analysis results. Review of Educational Research, 77(4), 454-499.

Marsh, H. W., \& Yeung, A. S. (1997). Causal effects of academic self-concept on academic achievement: Structural equation models of longitudinal data. Journal of Educational Psychology, 89(1), 41. 
Evans, C. R., \& Dion, K. L. (1991). Group cohesion and performance: A meta-analysis. Small Group Research, 22(2), 175-186.

Leithwood, K., Patten, S., \& Jantzi, D. (2010). Testing a conception of how school leadership influences student learning. Educational Administration Quarterly, 46, 671-706.

Abrami, P. C., Bernard, R. M., Borokhovski, E., Wade, A., Surkes, M. A., Tamim, R., \& Zhang, D. (2008). Instructional interventions affecting critical thinking skills and dispositions: A stage 1 meta-analysis. Review of Educational Research, 78(4), 1102-1134.

Byrne, B., \& Fielding-Barnsley, R. (1991). Evaluation of a program to teach phonemic awareness to young children. Journal of Educational Psychology, 83(4), 451-455.

The two studies in this corpus most frequently cited (above 2000 citations in Google Scholar) involve related measures around literacy/reading (Bus, Van IJzendoorn, \& Pellegrini, 1995) and learning environments (Angrist \& Lavy, 1999). It was found that parental/family involvement could impact early language growth, literacy, and reading (Bus et al., 1995) and elementary school learning environments by the reduction of class size to increase academic achievement (Angrist \& Lavy, 1999). Related to literacy, Byrne and Fielding-Barnsley (1991) found that children who possessed phonological awareness and knew their letter sounds could use this knowledge to decode unfamiliar printed words for reading. Additionally, Leithwood, Pattern, and Jantzi (2010), found that school leadership directly impacts the institution, the classroom, and family variables with powerful effects (43\%) on student achievement through school improvement and research/learning design.

Three studies in this short list of frequently cited publications, examined academic achievement in relation to the learner's conception of self. Academic self-concept and interest is reciprocal to student achievement (Marsh et al., 2005), but this measure of self-concept (skill-development) influences achievement (self-enhancement), which is also dependent on the age of the learner (Guay et al., 2003). Additionally, self-concept and academic achievement had larger effects for mathematics and science, over language arts and reading improvement (Marsh \& Yeung, 1997). Additionally, there is a stable and positive relationship between group cohesion and student achievement outcomes when learners are working cooperatively (Evans \& Dion, 1991).

Pedagogical practices and interventions were also tested in these top citations. A meta-analysis of teaching effectiveness studies was dominated by correlational and not causal (experimental or quasi-experimental) research designs (Seidel \& Shavelson, 2007). Also, critical thinking, as an instructional intervention, must include explicit objectives and instructions for student achievement, specifically by including these in pre-service teacher training and faculty development programs (Abrami et al., 2008).

\section{RQ4: What data collection and data analysis methods are used in the empirical studies international CLASS investigations?}

Based on the parameters of collecting causal impact studies, there were forty-two papers using a quantitative approach and five papers that deployed mixed methodologies for their research design.

Data collection. The majority of the papers used one experimental design (63.8\%) or two or more methods for quasi-experimental design approaches (36.2\%) to collect data for these investigations. In this corpus, $34 \%$ of the papers were meta-analyses of previous research studies and investigations. The most frequent data collection methods were through questionnaires or surveys $(44.7 \%)$, pre- and/or post-test

International Association of School Librarianship

https://iasl-online.org 
scores of academic interventions (23.4\%), and secondary analyses of standardized test data (19.1\%). Most studies collected descriptive statistics of the sample, population, site of study, dataset, or empirical literature collection. Other data collection methods used less frequently were interviews $(8.5 \%)$ and qualitative sources, such as focus groups or reflection papers $(4.3 \%)$.

Data analysis. The majority of the papers used at least one (59.6\%) or more often two or more (40.4\%) approaches for data analysis methods. Descriptive statistics were reported in almost all papers (91.5\%), except those who utilized secondary data collection (e.g. meta-analysis and/or database information). Thirty-four percent of the papers in this corpus were meta-analyses. Correlational statistics were used for all studies, as this was to evaluate the experimental, and quasi-experimental research methodology, utilized for these causal impact investigations. A select few $(10.6 \%)$ of the papers also included basic qualitative analysis methods, such as content analysis or theming, to assess the interview, focus group, or artifacts for these investigations.

RQ5: What is the focus of the international CLASS studies? What subjects, topics, or domains are being studied? And, what research questions are being asked within these empirical investigations?

In examining the studies in our corpus, there are a number of areas of focus with regard to the curricular subject, discipline, or topic of study. Sometimes these subject areas or domain of focus overlap. Table 4 identifies the frequency of curricular subject areas investigated in these publications by frequency (percentage).

\begin{tabular}{|lc|}
\hline $\begin{array}{l}\text { Table } 4 \\
\text { Frequency (Percentage) of Curricular Subject Area or Discipline of Study }\end{array}$ \\
\hline Curricular Subject Area/Domain of Study & Frequency (\%) of Total Papers ( $=47)$ \\
Reading, Writing, \& Language Arts & $40.4 \%$ \\
Mathematics & $38.3 \%$ \\
Science & $27.7 \%$ \\
General Studies; All Disciplines & $19.1 \%$ \\
Library and/or Information Technology & $17 \%$ \\
Study/Social Skills & $12.8 \%$ \\
\hline
\end{tabular}

We identified six categories describing the research reported in the corpus, based on each study's research questions. These areas of study involved: classroom setting and learning environment (8.5\%), student-focused issues and attributes $(21.3 \%)$, school, teacher and school leadership characteristics $(11.7 \%)$, instructional interventions and pedagogical practices $(19.1 \%)$, targeted academic skill development $(21.3 \%)$, and external factors for achievement, such as family, economics, community, etc. $(18.1 \%)$.

Classroom setting and learning environment. Studies in this category shared the size, set up, and management of the classroom. The review of learning environments emphasize how school librarians can impact typical educational settings and offer ways to embrace school librarianship as a transformative role for teachers and school administration. In looking at learning management, there are areas to assess student achievement with regard to classroom design and intervention programs that test group-based 
learning, student population size, and effectiveness of the educational environment. Summary of research questions for classroom setting and learning environments $(\mathrm{n}=4)$ :

- How does class-size impact instrumental variables' estimate of learner outcomes?

- What classroom-level factors are significantly related to a particular subject area?

- Does group cohesion impact student achievement in a positive way?

- What classroom-level factors and learning environment factors impact student success?

- How does an intervention program impact student success for future learning?

Student-focused issues and attributes. This category emphasizes the readiness and attitudes of students to learn. These studies examine attributes including cognitive, behavioral, affective, motivation, attitudes, skills and self-perception, with regard to their academic achievement. Summary of research questions for student-focused issues and attributes $(\mathrm{n}=10)$ :

- What student-level factors impact a particular subject area and/or learning level?

- What interventions fostering self-regulated learning are most effective?

- How does self-concept and student achievement influence each other?

- How is self-concept and achievement influenced by other variables, such as grades, gender, age, tests, subject area, school-level, self-esteem, over time, etc.?

- What are the student factors/characteristics that influence performance?

School, teacher, and school leadership characteristics. This category addresses the perceptions and relationships with school leadership, administrators, and teachers who may interact with school librarians. While the role of school personnel is addressed, there are also concerns with regard to the culture, climate, and positionality this institution has within society. Summary of research questions for school, teacher, and school leadership characteristics $(\mathrm{n}=5.5)$ :

How is reading achievement for students impacted by student and family factors?

How does teachers' professional competence for instruction impact student learning?

What classroom-level factors impact achievement, with regard to teacher quality?

How does school leadership influence student learning?

What school factors influence performance? School climate, context, or resources?

- What is the role of language and culture with regard to student achievement in Western school settings?

- What is the variability, by subject area, for student achievement within classrooms, between classrooms, and across schools?

- How does student achievement vary with regard to the teacher's gender, experience, level of education, major of study, and/or limitations?

Instructional interventions and pedagogical practices. This category identifies learning in context to specific models, frameworks, and instructional approaches. There are a number of teaching and learning practices to enhance the curriculum and overall assessment for student achievement. Theories and models tested in this corpus include critical thinking, project-based learning, self-regulated learning, self-concept, constructivism, reciprocal effects, cognitive evaluation/process, reciprocal effects, and path-goal theory. Summary of research questions for instructional interventions and pedagogical practices $(\mathrm{n}=9)$ :

How does critical thinking skills intervention affect student achievement?

What are the gaps for problem-based learning for group projects at various school levels?

- How does collaboration between a librarian and teachers impact student success?

- Do collaborative teaching approaches improve student achievement?

- What roles do school librarians and teachers take to provide student support?

- Does extrinsic reward detrimentally affect intrinsic motivation?

- What are the characteristics, goals, and conditions that moderate motivation for learning?

International Association of School Librarianship

https://iasl-online.org 
- What is the impact of the implementation of thinking skills on teaching and learning?

- What factors influence student interests with a particular instructional model/approach?

Targeted academic skill development. This category focuses on how educators and school librarians can support student achievement with specific skill development that will help overall learner success. This might be improving phonetics, reading, information literacy, note taking, writing, or research in a specific subject area or school level. Summary of research questions for targeted academic skills development $(\mathrm{n}=10)$ :

- How do library study skills instruction impact patterns of learning growth for students?

- How do phonemic awareness interventions impact/transfer to reading activities?

- Does direct instruction improve skill in intentional word learning?

- What are the student achievement effects of note-taking skills?

- How does promotional material for university impact/influence students' interests and expectations about postsecondary education?

- How does reading increase vocabulary development?

- How does bibliographic instruction support search and research proficiency for learners?

External factors for achievement. This category identifies studies that examine how non-school factors, such as family environments, socioeconomics, and community, impact and influence student achievement. These studies offer school librarians potential interventions and support. Summary of research questions for external factors for achievement $(\mathrm{n}=8.5)$ as:

- How does reading with parents/family/at home impact future literacy development?

- How does the language(s) spoken at home, parents' education, and home educational resources influence student achievement?

- How does family impact learner achievement as national income/GDP increases?

- What school factors outweigh family socioeconomic status for student achievement?

- Does the overall impact of schools vary across countries with different income levels?

- What cultural/economic/family constructs impact subject area student achievement?

- What are the relationships between students' ethnic/cultural background and that of the teacher proximity/influence, related to student outcomes and attitudes?

\section{Implications and Conclusions}

The geographic distribution of international scholarship shows that with the majority of international scholarship focused on North America (27.7\%), Europe (17.5\%), and Oceania (10.7\%) there is a need for increased empirical research from Africa or South America. As Morris and Cahill (2015) recognized, there is a "persistent imbalance of research conducted in English-speaking countries" (p. 16).

Internationally, despite an obvious need to consider context, a number of research areas could extend to identify effective practices that a school librarian or school library program and service could provide to positively affect student learning.

All six categories describing the focus of international research could be supported through continued research that would build a strong body of research that identifies specific dimensions known to impact student learning. We know that school libraries do make a difference. The challenge is articulating that difference in ways that the education community can understand and appreciate.

The ultimate goal of this research is to provide the tools and inspiration to produce accepted evidence of the effectiveness of school librarians in relation to student learning. The profession's foundation of correlational studies has provided the groundwork of school librarians' effectiveness. Now is the time to

International Association of School Librarianship

https://iasl-online.org 
extend that pursuit to establish evidence-based research internationally that illuminates the relationship between school librarians / school library programs and services and student learning.

Acknowledgement: This research is supported in part by the American Association of School Librarians through IMLS grants RE 62-13-0212-13 and RE-00-15-0114-15.
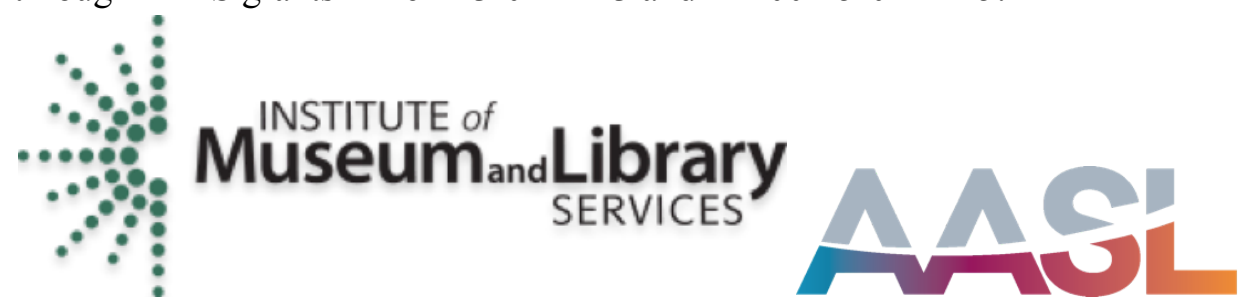

American Association of School Librarians TRANSFORMING LEARNING

CLASS II Researchers:

Florida State University (FSU): Marcia A. Mardis, Faye R. Jones, and Lenese M. Colson Old Dominion University (ODU): Sue Kimmel, Shana Pribesh, and Lois Wine University of North Texas (UNT): Barbara Schultz-Jones, Laura A. Pasquini, and Laura Gogia

\section{REFERENCES}

American Association of School Librarians [AASL]. (2014, December). Causality: School librarians and student success (CLASS). American Association of School Librarians National Research Forum white paper. Chicago, IL: American Library Association. Retrieved July 14, 2019 from http://www.ala.org/aasl/sites/ala.org.aasl/files/content/advocacy/research/docs/CLASSWhitePape r_FINAL.pdf

Branch-Mueller, J., \& Beesoon, G. (2015). School library research rocks: An examination of five years of school library research. In L. H. Das, S. Brand-Gruwel, J. Walhout, \& K. Kok. (Eds.). The School Library Rocks: Proceedings of the 44th International Association of School Librarianship (IASL) conference 2015, Volume II: Research Papers (pp. 22-41). Heerlen, Netherlands: Open Universiteit.

Everhart, N. (2018). Making the case for diversity in school library research. School Libraries Worldwide, 24(2), i-iii.

International Federation of Library Associations [IFLA]. 2015. IFLA School Library Guidelines. Retrieved July 13, 2019 from https://www.ifla.org/publications/node/9512

Institute of Education Sciences [IES], and National Science Foundation [NSF]. 2013. Common Guidelines for Education Research and Development. Retrieved February 8, 2019 from ies.ed.gov/pdf/CommonGuidelines.pdf.

Heyvaert, M., Maes, B., \& Onghena, P. (2013). Mixed methods research synthesis: definition, framework, and potential. Quality and Quantity, 47(2), 659-676. DOI: 10.1007/s111 35-011-9538-6 
Järvelin, K., \& Vakkari, P. (1990). Content analysis of research articles in library and information science. Library and Information Science Research, 12(4), 395- 421.

Johnston, M. \& Green, L.S. (2018). Still polishing the diamond: School library research over the last decade. School Library Research, 21, 1-63. Retrieved July 23, 2019 from http://www.ala.org/aasl /sites/ala.org.aasl/files/content/aaslpubsandjournals/slr/vol21/SLR_StillPolishing_V21.pdf

Library Research Service [LRS]. (2018). School Libraries Impact Studies. Retrieved July 13, 2019 from https://www.lrs.org/data-tools/school-libraries/impact-studies/

Lyons, Ray. (2009). The call for Evidence Based Practice: Speaking louder than words. Evidence Based Library and Information Practice (EBLIP), 4(3), 63-67.

Mardis, M. A. (2011). Evidence or evidence based practice? An analysis of IASL research forum papers, 1998-2009. Evidence Based Library and Information Practice 6(1): 4- 23.

Morris, R. J., \& Cahill, M. (2017). A study of how we study: Methodologies of school library research 2007 through July 2015. School Library Research 20, 1-30. http://www.ala.org/aas1/sites/ala.org .aasl/files/content/aaslpubsandjournals/slr/vol20/SLR_HowWeStudy_V20.pdf

Neuman, D. (2003). Research in school library media for the next decade: Polishing the diamond. Library Trends 51(4), 503-524.

Oberg, D. (2006). School Libraries Worldwide as a source for evidence for evidence based practice, 1995-2006. School Libraries Worldwide, 12(2), i-xii.

Pawson, R. (2006). Evidence-based policy: A realist perspective. London: Sage.

Pence, A.R. and Hix-Small, H. (2009) Global children in the shadow of the global child. International Critical Childhood Policy Studies 2(1), 75-91.

Sandelowski, M., Voils, C. I., Leeman, J. \& Crandell, J. L. (2012). Mapping the mixed methods-mixed research synthesis terrain. Journal of Mixed Methods Research, 6(4), 317-331. Retrieved February 3, 2019 from https://www.ncbi.nlm.nih.gov/pmc/articles/PMC3467952/

Sandelowski, M., Voils, C. I. \& Barroso, J. (2006). Defining and designing mixed research synthesis studies. Research in the Schools, 13, 29-40. Retrieved February 3, 2019, from https://www .ncbi.nlm.nih.gov/pmc/articles/PMC2809982/

Schultz-Jones, B., Kimmel, S., Mardis, M., Jones, F., Pribesh, S., \& Pasquini, L. (2018). Evidence, standards, and school librarianship: Prevailing policies, promising methods, and progress on a research agenda. School Libraries Worldwide, 24(2), 17-29.

Todd, R. (2006). School libraries and evidence-based practice: An integrated approach to evidence. School Libraries Worldwide, 12(2), 31-37. 
Todd, R. J. (2009). School librarianship and evidence-based practice: Progress, perspectives, and challenges. Evidence Based Library and Information Practice, 4(2), 78-82.

Todd, R. (2015). Evidence-base practice and school libraries: Interconnections of evidence, advocacy, and actions. Knowledge Quest, 43(3), 8-15.

United States. Department of Education. (2004). A Guide to Education and No Child Left Behind. Retrieved January 31, 2019, from https://www2.ed.gov/nclb/overview/intro/guide/index.html

United States. Department of Education. (2016). Non-regulatory guidance: Using evidence to strengthen education investments. Retrieved January 31, 2019, from https://www2.ed.gov/policy/elsec/leg /essa/guidanceuseseinvestment.pdf

Williams, D., Wavell, C. \& Morrison, K. (2013). Impact of school libraries on learning: Critical review of evidence to inform the Scottish education community. Retrieved July 13, 2019 from https://core.ac.uk/download/pdf/42534924.pdf

\section{Participant Biographies}

Laura Pasquini is a senior lecturer in the Learning Technologies Department, College of Information, University of North Texas, Denton, Texas, USA.

Barbara Schultz-Jones is an associate professor and Director of the School Library Certification and Youth Librarianship Programs in the Information Science Department at the University of North Texas, Denton, Texas, USA. 